\title{
Hydrological engineering for sustainable shifting agriculture in the Eastern tropical Himalayas: A conceptual discussion
}

\author{
R. Zonunsanga, Joe Magner* \\ Department of Bioproducts \& Biosystems Engineering, University of Minnesota, MN 55Io8, USA
}

\begin{abstract}
Shifting agriculture has been regarded as the cause of degradation to most types of natural resources in the Eastern Himalayas. Attempts have been made by certain agencies to abolish the system or find alternatives but failed. Physical barriers arising from rugged topography along with the socio-economic conditions are the major hindrances for improved agricultural systems. Discussions on problems related to shifting agriculture and natural resources conservations have been made based on literature review and researches conducted in the region. Rainfall and vegetative cover being the major determinants of erosion intensity in the region, hydrological engineering model for on-farm soil conservation practices has been developed to control runoff, enhance rainfall interception and retain soil moisture and organic matter. Measures for on-site soil conservation include the use of locally available resources with the application of simple technology and economically inexpensive for the ignorant and poor marginal farmers.
\end{abstract}

Key words: Crop residue; erosion; Himalayas; infiltration; interception; monsoon; shifting agriculture, runoff.

\author{
Received 20 March 2017 \\ Accepted 20 June 2017 \\ *For correspondence $\bowtie:$ \\ ascassdir@gmail.com
}

\section{Introduction}

The system of shifting agriculture has been paraphrased "necessary evil" for its negative preconception towards degradation of land, water and forest resources. Known to the locals as jhumming, it is still the most prevalent form of agriculture practiced by the tribal groups of Northeast India in the extreme Eastern Himalayas.

No doubt that the system of shifting agriculture, like any other agricultural systems, has tremendous impact towards degradations of natural resources and environment. Scientific publications on shifting cultivation reveal that the systems have certain merits and advantages while most studies recognize as imposing serious threats to the environs. In fact, the sustainability of shifting cultivation is presently a topic of debate and as a result, the system has gained interest of scientific community and policy makers and has further added its popularity due to the failure of several attempts that have been carried out to abolish or find alternatives.

\section{Problems in the Eastern Himalayas}

The root cause of all problems associated 
with the systems of shifting cultivation is soil erosion. Excessive rate of erosion on jhum-lands upshot nutrients loss making the sites unsuitable for further cultivation and hence shifting of agricultural lands in a nomadic manner. The physical factors contributing to the massive soil losses are, therefore, the main problems in the Eastern Himalayas. Other hindrances comprise of formulating measures to combat such physical constraints and mostly the existing socioeconomic and political conditions which impose certain limitations to overcome the problems of natural resources degradation.

The Himalayan and Tibetan regions cover only $5 \%$ of the Earth's land surface, but supply about $25 \%$ of the dissolved load to the world ocean. ${ }^{1}$ The Eastern Himalayas comprise of sandstone, shale and conglomerates with the characteristics of fluvial deposits and with deep soils and, these formations are geologically weak, unstable and hence highly prone to erosion. ${ }^{2}$ Being predominantly of mountainous terrain and hill ridges separated by deep valleys, the loose sandy soil covers are highly susceptible to detachment by rain splash and erosion by runoff.

Owing to its tropical-monsoon location, the region also exhibits one of the World's most precipitous zones with large network of river systems. The Brahmaputra River, which drains the many parts of eastern Himalaya, is the fourth largest river in the world in terms of average discharge, but second in terms of sediment transport per unit drainage area. ${ }^{3}$ Amidst the several adverse physical conditions, the region has, however, high forest cover percentage which has greatly reduced the rate of erosion.

The United States Department of Agriculture (USDA-NRCS) has placed the whole of Arunachal (Eastern Himalaya) under "high to very high" water erosion vulnerability category, and "very high' human-induced water erosion category. ${ }^{4}$ Other researches on soil erosion, conducted in the region at different watershed level also revealed that the rate of soil erosion is very high. Rawat et al. ${ }^{5}$ and Dabral et al. ${ }^{6}$ estimated erosion in one of the hilly catchments of Eastern Himalayas where the average soil loss and sediment yield amounted to $440.33 \mathrm{t} \mathrm{ha}^{-1}$ year $^{-1}$ and 155.53 $\mathrm{t} \mathrm{ha}{ }^{-1}$ year $^{-1}$ respectively. A basic research on soil loss conducted in one of the watersheds in Mizoram also shows that the intensity of soil loss is highly associated with the type and density of forest covers which protect soils from rainfall impact. ${ }^{7}$

Equally important with the above physical hindrances are the problems arising from the socio-economic conditions where majority of the shifting cultivators are too poor to carry out improved agricultural systems and farm mechanization. It is a subsistence type of agriculture with the least surplus for market. Besides, tribal farmers have their culture strongly bonded and associated with the shifting agriculture that practicing other systems of agriculture would mean abandoning the tribal culture and their way of life. The livelihood systems make most indigenous peoples fundamentally reliant on the environment and natural resources for their daily existence and; this reliance on natural resources has become integral to their way of life and their self-identification. ${ }^{8}$ The traditional farming system of jhumming is linked with the ecological, socio-economic and cultural life of the indigenous people and is closely connected to their rituals and festivals that revolve around the jhum fields; not just as a means of their livelihood, but as a way of life. ${ }^{9}$

\section{Challenges to Bring Transformation}

It has been learnt that the geophysical conditions and prevailing land use systems in the Eastern Himalayas impose serious threats to the environment and that several attempts have been made to replace shifting cultivation but failed. Recommendation to abolish the system proved impracticable if one considers the harsh physical environs, poor economy, primitive culture and available technology in the region. It is in this type of situation where slight but strong modification has to be implemented, rather than recommendation of alternatives.

Implementation of soil conservation measures within the agricultural sites could be one amongst the best actions as soil erosion has 
been proven one of the major factors resulting to degradation of environments. But soil conservation always means change ${ }^{10}$ in which several types of change could be recommended depending upon the determinants of soil degradation for each specific location. The main problems arise when the types of change recommended are not at all possible and feasible, especially in the under-developed region where famers do not afford application of mechanical measures nor have the knowledge to implement sophisticated techniques. Hence, recommendations for implementation of such conservative, control or improvement measures should take into account only such processes which are physically sustainable, economically affordable, technically applicable and culturally acceptable.

Landscapes may be sculptured in such a way that the slopes are levelled and the depressions filled; but situations are always otherwise where socio-economic conditions wipe out all the possibilities. The pouring monsoons cannot be controlled or diverted and the soils are too impaired for natural resilience. One of the few options available is to dissipate the forces within each processes of the hydrological cycle acting on the land surfaces by means of biosystems engineering measures which are economically affordable, mechanically available, technically simple and culturally acceptable. Such measures would make the tribals' Jhum sites more sustainable for perennial use and lengthen the period of jhum cycle and hence reduce degradation of forest resources, enhance water resources as well as the economy of the farmers.

\section{Hydrologic Engineering for Sustainable Jhumming System}

It has now been learnt that the problems of shifting cultivation in the Eastern Himalayas revolve around the hydrologic cycle and pathways resulting to degradation of natural resources. The agents of soil removal from agricultural sites being raindrops impact and runoff, biosystems engineering could be a helpful measure to reduce soil loss and enhance soil health for a sustainable jhumming system. Use of agro- forestry, contour cropping, physical and vegetative erosion barriers, or integrated weed management is found to reduce soil degradation and surface erosion on farms. ${ }^{11}$

Biosystems engineering is a discipline which integrates engineering science and design with applied biological, environmental and agricultural sciences. The conceptual models to improve sustainability of jhumming in this paper, therefore, include designs of structural engineering using the locally available biotic resources with special considerations on the prevailing geo-environmental conditions and agricultural system. Such methods have to consider measures for soil erosion control in jhum cultivation sites comprising of techniques or systems to cope with the knowledge of ignorant farmers and the freely available biotic natural resources. The subsistent farmers have to continue the cultivation of their jhum sites and only the simplest modifications have to be implemented to ally with their cultural and traditional practices. Shifting cultivation throughout the tropics is largely subsistence activity practised in areas with few alternative options and is likely to continue. ${ }^{12}$ The recommended measures should be affordable by the poor jhummias or be the least expensive ones in terms of monetary and time. Considering these two socio-economic constraints, the following hydrological processes have to be controlled using biosystems measures:

\section{Runoff}

Velocity of runoff increases and gains its erosive power with increasing slope length. From the academic point of view, there can be several measures to control runoff such as constructions of terraces, infiltration ditches etc. which are but not viable to the poor marginal farmers. Shifting agricultural systems all over the world share common practice which is burning of the dried vegetation where many trees and their branches remain half-burnt. These remnants, free of cost, can be used to control runoff by placing them along the slopes where rills are likely to develop and all across the slope as con- 
tour lines at regular intervals. Contouring across the slope shorten the slope length and reduce runoff velocity whereas those along the slope prevent runoff to get confined in a single erosive channel. Rill erosion rates increase with discharge. ${ }^{13}$ The contour structures have to be in touch with the ground surface to avoid chances of runoff creeping through it. Seeds of selected crops may be sown along these lines to support stability of the structures. Such rows can also be replaced by harvestable crops such as broom grass, tea plantations, fodder plants, nitrogen fixing legumes to supplement supply of nutrients to the crops, ${ }^{14}$ and to act as narrow buffer lines for the adjacent plots just down below.

Weeds are one among the problems in jhum sites especially in the precipitous tropical region where they compete and thrive faster than the crops. During weeding, some of the unwanted weeds may be placed for decomposition along the lines of contour structures evenly so as to ensure complete blockade of seeping runoff and supply of nutrients after decomposition. To control pollutants and sediment transport to the streams, buffering at the lowest part of jhum sites should also be encouraged, which is of course a common one. Sandstones of different sizes, found in almost the entire region, should be placed along the confined channel to enhance turbulence and dissipation of runoff erosive energy.

\section{Interception}

Interception of raindrops by canopies of trees, plants and crops act positively in three different ways - reducing the amount of raindrops reaching the ground; dissipating the energy of raindrops impact on the soils and; providing shades to reduce evapotranspiration from soil underneath. The type, extent and condition of vegetation and plant litter influence the pattern of deposition and the amount of precipitation reaching the soil surface. ${ }^{15}$ Soil loss intensity map in the Himalayan watershed interestingly follows the pattern of slope distribution and more importantly the pattern of vegetation density. ${ }^{16}$
A food system based on only two or three food crops is extremely vulnerable to risks and is likely to be nutritionally unbalanced. ${ }^{17}$ Shifting cultivation also has been known as comprising mixed cropping where different kind of crops are grown together to minimize risks and provide maximum production from all sources. Interception of precipitation in this system, despite the mixed cropping, proved to be insufficient as the amount of soil loss from jhum sites is still very high. To overcome this problem, trees with different types of canopy cover should be left over at regular intervals while cutclearing the lands where trees with extensive canopy and thick bark should be selected for maximum interception and to withstand burning of the jhum plot.

Several crops and fruits thrive in the region owing to its geographical location where the prevailing temperature and precipitation provide favourable conditions. Selection of the right crops with multi-tier canopy heights for maximum interception is therefore a prerequisite task. Besides, considerations have to be given towards generation of income from certain crops during the first year for the poor marginal farmers to enable them carry out additional conservative measures in their jhum sites in the following years.

\section{Evapotranspiration}

Reducing evapotranspiration from soil using crops residues or mulching has several advantages such as enhancing the amount of water available for the next cropping season and, rates of organic accumulations and water infiltration.

Crops residue evenly distributed over the soil surface protects the soil from direct impact of raindrops by absorbing energy of raindrops, and further insulates the wet soil from solar energy and reduces evaporation. ${ }^{18}$ The Eastern Himalayas provide a condition where all kinds of weeds and plants grow abundantly that weeding has become a necessary routine at regular interval. Such unwanted plants, after weeding, should be used as residue cover to enhance infiltration, moisture retention, accumulation of organic 
matter and soil conservation from raindrops impact. Management of residues from the monsoon crops can have significant impact on soilwater availability if cropping has to be done during the following less precipitous winter season. Crops residue provides erosion protection, serves as a source of plant nutrients to following crops, and reduces the amount of rainfall runoff. ${ }^{19}$

In the context of dry winter season cropping in the Eastern Himalayas, precipitation in most parts of the region occurs in the form of dews or snow-dews which have insignificant potential to erode soil but moisture of the upper soil surface. Retention of this soil moisture could provide water for the crops grown during dry winter seasons. Crops such as broccoli, cabbage, brinjal, chilly, beans or cow-peas and mustard can be grown during tropical winter ${ }^{20}$ and these crops could offer market value to the farmers and domestic consumption as well. It may be noted that legumes among other crops, in addition to its role as a source of protein $\mathrm{N}$ in the diet, $\mathrm{N}$ from legumes fixation is essentially "free" $\mathrm{N}$ for use by the host plant or subsequent crops. ${ }^{21}$ To augment crops and residue during less precipitous winter temperature, classification of local crops has to be done based on their tolerance to tropical winter climate.

\section{Conclusion}

Farmers in the eastern tropical Himalayas suffer greater extremes of physical and economic conditions. To be sustainable, small resource-poor farms in the tropics will depend increasingly on recycling organic materials to improve soil architecture and return plant nutrients. ${ }^{22}$ Measures to improve sustainability of jhumming systems should never aim at drastic changes but gradual transformation through introduction of minor modifications and use of local resources and knowledge. Resources accessibility, economic viability, social acceptability and knowledge availability have to be considered to formulate a model based on holistic approaches. Gradual transformation of jhum sites into permanent cultivations may have to go a very long way that one should firstly make an attempt to lengthen the jhum cycle period. Sustainability of the fragile eco-region can be managed through maintaining longer fallow period. ${ }^{23}$

\section{References}

I. Raymo, M.E. \& Rudiman, W.F. (1992). Tectonic forcing of Late Cenozoic climate. Nature 359, II7-I22.

2. Jain, S.K., Kumar, S. \& Varghese, J. (200I). Estimation of soil erosion for a Himalayan watershed using GIS technique. Water Resource Management I5, 4I-54.

3. Kotoky, P., Bezbaruah, D. Baruah, J. \& Sarma, J.N. (2005). Nature of bank erosion along the Brahmaputra river channel, Assam, India. Current Science 88, 634640.

4. Reich, P. \& Eswaran, H. (200I). Global dimensions of vulnerability to wind and water erosion. In (D.E. Sttot. R.H. Mohtar \& G.C. Steinhardt, eds.) Sustaining the Global farm. Selected papers from the $10^{\text {th }}$ International Soil Conservation Organization Meeting, May 24-29, 1999. USDA-ARS, Washington DC.

5. Rawat, J.S., Joshi, R.C. \& Mesia Momme (2013). Estimation of erosivity index and soil loss under different land uses in the tropical foothills of Eastern Himalayas (India). Tropical Ecology 54 (I), 47-58.

6. Dabral, P.P., Baithuri, N. And Pandey, A. (2008). Soil erosion assessment in a hilly catchment of Northeast India using USLE, GIS and remote sensing. Water Resource Management 22, 1783-1798.

7. Zonunsanga, R., Rao, U.B. \& Rinawma, P. (2014). Degradation of Land and Forest Resources: The story of shifting cultivation and loss of biodiversity in NE India. In (Mehtab Singh, R.B. Singh \& M.I. Hassan, eds) Climate Change ES Biodiversity, Proceedings of the International Geographical Union, 2013, Rohtak, India, VolI. Springer Publications.

8. FAO. (2009). Indigenous and tribal people: building on biological and cultural diversity for food and livelibood security, 9 .

9. Tangjang, S. (2009). Traditional Slash and Burn Agriculture as a Historic Land Use Practice: A Case Study from the Ethnic Noctes in Arunachal Pradesh, India. World Journal of Agricultural Sciences 5 (I), 70-73.

Io. Hurni Hans (1982). Soil Erosion: Concern and Con- 
straint. Mountain Research Development 2 (2), I4I-I56.

II. Zaitchik, B.F. \& van Es, H.M. (2003). Applying a GIs slope-stability model to site-specific landslide prevention in Honduras. Journal of Soil and Water Conservation 58 (I), 45-53.

I2. Karthik, T., Gopi, G.V. \& Prasanna, K.S. (2009). Forest recovery following shifting cultivation: An overview of existing research. Journal of Tropical Conservation Science 2 (4), 374-387.

13. Govers, G. \& Loch, R.J. (1993). Effects of initial water content and soil mechanical strength on the runoff erosion resistance of clay soils. Australian Journal of Soil Resources 31, 549-566.

14. Lalramnghinglova, H. (20I5). Sustainable agroecosystem in eastern Himalayas: the Changkham Model (Case study from Mizoram) In (K. Eckman and L. Ralte, eds.): Integrated Land Use Management in the Eastern Himalayas. Akansha Publishing House, New Delhi, India.

I5. Brooks Kenneth N., Ffolliott Peter F. \& Magner Joseph A. (2013). Hydrology and the Management of Watersheds. Wiley-Blackwell. $4^{\text {th }}$ Edition. John Wiley \& Sons. Inc.
16. Zonunsanga, R. (2016). Estimation of Soil loss in Teirei watershed of Mizoram by using the USLE Model. Science and Technology Journal 4 (I), 43-47.

17. Ramakrishnan, P.S. \& Saxena, K.G. (1996). Conservation and Management of Biological Resources in Himalaya. Oxford \& IBH, pp: 3-26.

18. Moore, E.L. (2015). Tillage, residue management and their effect on soil moisture. Drought Management Factsheet No. 8, Ministry of Agriculture, British Columbia.

19. Larson, W.E. (1979). Crop residues: Energy production or erosion control. Journal of Soil and Water Conservation 34, 74-76.

20. Attfield, H.H.D. (20oI). A Tropical Guide to Year Round Vegetable Gardening. A Vita Publication. p. 6.

2I. Graham, P.H., Vance, C.P. (2003). Legumes: Importance and constraints to greater use. Plant Physiology I31, $872-877$.

22. Shaxson, T.F. (1996). Conservation at the crossroads in tropical countries. Journal of Soil and Water Conservation SI (6), 47I.

23. Nath, A.J., Brahma, B., Lal, R., Das, A.K. (2016). Soil and Jhum Cultivation. in Encyclopedia of Soil Science, Taylor \& Francis. 